\title{
Problem Davranışların Azaltılmasında İşlevsel İletişim Öğretiminin Kullanımı
}

\section{Semra OMAK*}

Öz: Özel gereksinimli çocuklarda problem davranışların azaltılması ve iletişim gereksinimlerini karşılayabilecek iletişim davranışlarının öğretilmesinde etkili bir bilimsel dayanaklı müdahale olan işlevsel iletişim öğretimi kullanılmaktadır. İşlevsel iletişim öğretimi müdahalesinin amacı, problem davranışın işlevini tanımlamak ve daha sonra problem davranışla aynı işleve sahip uygun bir iletişim davranışı öğretmektir. Bu bağlamda bu çalışmanın amacı, işlevsel iletişim öğretimi ve uygulama sürecine ilişkin kapsamlı bilgiler sunarak bu müdahaleyi ailelere ve eğitimcilere tanıtmaktır. Problem davranışların azaltılmasında işlevsel iletişim öğretiminin kullanımına ilişkin alanyazına katkıda bulunmak amacıyla yapılan bu çalışma, literatür taraması ile yapılan bir derleme çalışmasıdır. Araştırmada işlevsel iletişim öğretimi ve işlevsel iletişim öğretiminin uygulama adımları, genel özellikleri çerçevesinde tanıtılmış ve buna ilişskin önerilere yer verilmiştir. Bu amaçla, çalışmada ele alınan işlevsel iletişim öğretimine ilişkin temel kaynaklara ulaşılmış ve bu müdahale yöntemine ilişkin bilgiler derlenmiştir.

Anahtar Kelimeler: Problem davranış, işlevsel iletişim öğretimi, özel gereksinimli çocuklar, işlevsel davranışsal değerlendirme, iletişim davranışı.

\section{Using of Functional Communication Teaching in Reducing Problem Behaviour}

\section{Views}

Abstract: An efficient and scientifically-based intervention, the functional communication teaching is used to reduce the problem behaviours of children with special needs and to teach communicational behaviours that can meet their communicational needs. The purpose of the intervention of the functional communication teaching is to determine the problem behaviour and later to teach a proper communication behaviour possessing the same function as the problem behaviour. In this context, the purpose of this study is to introduce this intervention to

*Araş. Gör. Ahi Evran Üniversitesi, Eğitim Fakültesi, Zihin Engellilerin Eğitimi Anabilim Dalı, email: semra.omak12@hotmail.com Orcid No: https://orcid.org/0000-0002-2367-9736 
families and educators by presenting comprehensive information on both functional communication teaching and its application. In order to contribute to the field literature on using the functional communication teaching to reduce problem behaviour, this study is a descriptive research done through literature screening. In this research, both the application steps of functional communication teaching and the functional communicational teaching itself were introduced within the framework of their general properties and relative recommendations were given. For this purpose, essential resources concerning the functional communication teaching presented in this study were acquired and information regarding to this intervention method were gathered.

Key Words: Problem behaviour, functional communication teaching, children with special needs, functional behavioral assessment, communication behaviour.

\section{Giriş}

İnsan, kendine özgü özellikleri olan sosyal bir varlıktır ve çevresindekilerle sürekli iletişim halindedir. İletişim, etkileşimde bulunulan diğer insanlara bilgi aktarmayı hedeflemek ve hedeflenen mesajın algılanabilmesine hazırlıklı olmaktır (Konrot, 2009; Topbaş, 1999). İnsanlar duygu ve düşüncelerini paylaşmak, aynı zamanda dilek, istek ve gereksinimlerini uygun şekilde aktarabilmek amacıyla iletişim kurmaktadırlar (Diken, 2013).

İletişim, bir gereksinimdir (Konrot, 2009). İletişim kurma gereksinimi ve yeterliliği doğumla birlikte başlar ve yaşam boyu devam eder. Çoğu çocuk, yaşamında önemli bir yere sahip olan iletişim kurmayı, toplum içerisinde kendiliğinden edinir; ancak bazı çocuklar çeşitli nedenlerle iletişim kurmada güçlük yaşar ve toplumsal yaşama uyumu sağlayamazlar (Toğram, 2004). Dolayısıyla bu gereksinimi karşılamak amacıyla da farklı biçimlerde problem davranışlar sergilerler. Problem davranışlar; çocukların kendisinin ya da başkalarının öğrenmesine engel olan, toplumda etkili işlevde bulunmasını engelleyen, hem kendisinin hem de başkalarının güvenliğini tehlikeye düşüren, sosyal ilişkileri ve etkileşimi olumsuz yönde etkileyen, aynı zamanda çocuğun yaşına ve yaşadığı toplumun kültürel normlarına uymayan davranışlardır (Carr ve Durand, 1985; Erbaş, 2001). Çocuklar; kendisine veya çevreye zarar verme, saldırganlık, öfke nöbetleri, bağırma, etkinliğe katılımı reddetme, verilen görevi tamamlamama gibi farklı problem davranışlar sergileyebilmektedirler. Bu davranışlar; çocukların eğitsel gereksinimlerinin karşılanmasını zorlaştırarak akranları gibi eğitim olanaklarından yararlanmalarına engel olur, eğitimcilerin öğretim için daha fazla zaman ve emek harcamasına neden olur ve çocukların aile içinde ve akranlarıyla olumsuz ilişkiler 
geliştirmelerine yol açar (Erbaş, Kırcaali İftar ve Tekin İftar, 2011). Alanyazında, problem davranışların nedenleri farklı şekillerde ele alınıp sınıflandırılsa da problem davranışların çevresel olaylardan kaynaklandığına ilişkin görüşe göre, her davranış belirli bir amaca ulaşmak için sergilenir (Yücesoy Özkan, 2013). Dolayısıyla problem davranışların da belirli bir amacı vardır ve belirli bir işleve hizmet ederler (Alberto ve Troutman, 2013; Cooper, Heron ve Heward, 2019; Erbaş, 2001; Yücesoy Özkan, 2013). Alanyazında, problem davranışların işlevlerine ilişkin olumlu pekiştirme yoluyla elde etme ve olumsuz pekiştirme yoluyla kaçma/kaçınma olmak üzere ikili bir sınıflama biçimi benimsenmektedir (Alberto ve Troutman, 2013; Cooper vd., 2019; Erbaş, 2017; Erbaş, Kırcaali İftar ve Tekin İftar, 2011).

Olumlu pekiştirme yoluyla elde etme: Çocuklar çoğunlukla problem davranışları sosyal ilgi ve dikkat elde etme, nesne elde etme ve duyusal uyaran elde etme gibi hoşa giden bir uyaran elde etmek amacıyla sergilemektedirler (Alberto ve Troutman, 2013; Cooper vd., 2019; Erbaş, Kırcaali İftar ve Tekin İftar, 2011). Çocuğun öğretmeninin ilgisini çekmek için sürekli masaya vurması ve öğretmenin ilgisini çocuğa yöneltmesi, grup içerisinde oyun oynayan çocuğun arkadaşının elindeki oyuncağı almak için ona vurması ve oyuncağı elde etmesi veya çocuğun sallanarak duyusal uyaran elde etmesi çocuğun bu davranışları ileride de sergilemeye devam etmesine neden olur. Çocuğun bu davranışları ilgi, nesne ve duyusal uyaran elde etmeyle sonuçlandığı için bu durumda problem davranışın işlevi, olumlu pekiştirme yoluyla elde etme olur.

Olumsuz pekiştirme yoluyla kaçma/kaçınma: Problem davranışların işlevlerinden ikincisi olumsuz pekiştirme yoluyla kaçma/kaçınmadır. Çocuklar problem davranışları hoşuna gitmeyen veya kendilerine zor gelen etkinlik, nesne, sosyal etkileşim ya da duyusal uyarandan kaçmak amaciyla da sergileyebilmektedirler (Butler ve Luiselli, 2007; Durand, 1990). Öğretmenin verdiği ev ödevlerini yapmakta zorlanan çocuğun bağırması ve annesinin ödevlerini yapmamasına izin vermesi, öğretmenin kendisiyle ilgilenmesini istemeyen çocuğun ağlaması ve öğretmenin çocuğun yanından uzaklaşması ya da diş ağrısı çeken çocuğun ağrıyı azaltmak için sürekli yanağına vurması çocuğun bu davranışları ileride de sergilemesine neden olur. Çocuğun problem davranışları etkinlikten, kişiden ya da duyusal uyarandan kaçmayla sonuçlandı̆̆ 1 için bu durumda problem davranışın işlevi, olumsuz pekiştirme yoluyla kaçma/kaçınma olur.

Özel gereksinimli çocukların da problem davranışları, iletişim kurmanın bir yolu olan öğrenilmiş davranış veya davranış dizisidir. Bu çocuklar problem davranışının arzu edilen bir sonuca ulaştığını, onu güvenilir bir şekilde takip eden sonuçlarla işlevsel olarak ilişkili 
olduğunu öğrenmiştir (Foxx ve Meindl, 2007). Davranışsal müdahale araştırmaları, daha etkin öğrenme ve verimli bir iletişim için problem davranışların önemli ölçüde azaltılması gerektiğini vurgulamıştır. Problem davranışlara müdahalede en çok araştırılan davranışsal müdahalelerden biri de işlevsel iletişim öğretimidir (Alpdoğan, 2018; Erbaş, 2001; Hagopian, Contrucci Kuhn, Long ve Rush, 2005; Hanley, Iwata ve Thompson, 2001; Fisher, Thompson, Hagopian, Bowman ve Krug, 2000;Tiger ve Hanley, 2004; Tiger, Hanley ve Heal, 2006).

\section{Çalışmanın Önemi ve Amacı}

Etkili öğretim müdahalelerinin uygulanmaması sebebiyle problem davranışlarla baş edebilmek, hem aileler hem de eğitimciler tarafından karşı karşıya kalınan ciddi bir sorundur. $\mathrm{Bu}$ nedenle, aileler veya eğitimciler problem davranışlarla baş edebilme sürecinde farklı öğretim müdahalelerine ihtiyaç duymaktadır. Özel gereksinimli çocukların problem davranışlarının azaltılması ve iletişim gereksinimlerini karşılayabilecek iletişim davranışlarının öğretilmesinde etkili bir bilimsel dayanaklı müdahale olan işlevsel iletişim öğretimi kullanılmaktadır (Alpdoğan, 2018; Erbaş, 2001). İşlevsel iletişim öğretiminin amacı, problem davranışın işlevini tanımlamak ve daha sonra problem davranışla aynı işleve sahip uygun bir iletişim davranışı öğretmektir. Bu yönden işlevsel iletişim öğretimi müdahalesinin aileler ve eğitimciler tarafından bilinmesi ve etkili bir biçimde kullanılabilmesinin önem arz ettiği düşünülmektedir. Bu bağlamda bu çalışmanın amacı, işlevsel iletişim öğretimi ve uygulama sürecine ilişkin kapsamlı bilgiler sunarak bu müdahaleyi ailelere ve eğitimcilere tanıtmaktır.

\section{Yöntem}

Problem davranışların azaltılmasında işlevsel iletişim öğretiminin kullanımına ilişkin alanyazına katkıda bulunmak amacıyla yapılan bu çalışma, literatür taraması ile yapılan bir derleme çalışmasıdır. Literatür taraması, araştırma problemiyle ilgili bilgilerin özeti, sentezi ve incelemesidir (Balc1, 2013). Araştırmada problem davranışların azaltılmasında kullanılan işlevsel iletişim öğretimi ve işlevsel iletişim öğretiminin uygulama adımları, genel özellikleri çerçevesinde tanıtılmıştır. Bu amaçla, çalışmada ele alınan işlevsel iletişim öğretimine ilişkin temel kaynaklara ulaşılmış ve bu müdahale yöntemine ilişkin bilgiler derlenmiştir. Çalışmaya ilişkin veriler, çeşitli veri tabanlarından konuyla ilgili makale, tez, bildiri, proje ve internet siteleri üzerinde toplanmıştır. Elde edilen verilerle, problem davranışların azaltılmasında kullanılan işlevsel iletişim öğretimine ilişkin alanyazına katkıda bulunmaya ve konunun önemine dikkat çekilmiştir. 


\section{Bulgular}

\section{İşlevsel İletişim Öğretimi}

İşlevsel iletişim öğretimi, problem davranışı tanımlamaya ve problem davranışla aynı işlevi taşıyan sosyal olarak uygun bir iletişim davranışını öğretmeye odaklanan pekiştirmeye dayalı bir davranış değiştirme müdahalesidir (Carr ve Durand, 1985; Durand ve Carr, 1992). İşlevsel iletişim öğretimi, problem davranışların kişinin ihtiyacını karşılama aracı olabileceği teorisine dayanan bilimsel dayanaklı bir müdahaledir (Kurtz, Boelter, Jarmolowicz, Chin ve Hagopian, 2011; Mancil, 2006; National Clearinghouse on Autism Evidence and Practice [NCAEP], 2020). Bu müdahalenin genel amacı, problem davranışlar için uygun bir iletişim biçimini kullanmaktır (Mancil ve Boman, 2010). İşlevsel iletişim öğretiminin etkili ve eğitici bir müdahale olarak tercih edilmesinin nedenleri şöyle sıralanabilir (Meyer ve Evans, 1989):

- İletişim becerilerini arttırmada ve problem davranışları azaltmada etkilidir.

- $\quad$ Edinilen becerilerin/davranışların kalıcılığının ve genellemesinin sağlanmasında etkilidir.

- Davranış değiştirmede kullanılan diğer müdahalelerle kıyaslandığında daha 1lımlıdır ve sosyal geçerliği yüksektir.

- $\quad$ Bu müdahale uygulama açısından kolay ve pratiktir.

- $\quad$ Özel gereksinimli çocuklara yönelik olumlu tutumların gelişmesine katkı sağlar.

İşlevsel iletişim öğretiminin kullanımında üç aşamalı bir süreç izlenmektedir. İlk aşama, uygulayıcının işlevsel davranışsal değerlendirme sürecini tamamlamasıdır. Bu değerlendirme, uygulamacının problem davranışın hangi işlevi (olumlu pekiştirme yoluyla elde etme veya olumsuz pekiştirme yoluyla kaçma/kaçınma) yerine getirdiğini belirlemesine yardımcı olur. İkinci aşamada uygulamacı sözel dil, işaret dili, resim iletişimi veya bir alternatif iletişim cihazı gibi daha uygun ve evrensel olarak anlaş1lan bir iletişim biçimi seçer. Bu yeni iletişim biçimi, çocuğun istediği mesajını iletmesine izin verecektir (örneğin, "Ben sıkıldım ve bunu durdurmak istiyorum" anlamına gelen alternatif iletişim cihazını kullanarak) ve böylece problem davranışa olan ihtiyacını azaltacaktır. Son aşama ise, çocuğa kabul edilebilir iletişim davranışını öğretmek için bir müdahale planının geliştirilmesidir. Bu aşamada uygulamacı, çocuğa problem davranışla aynı işleve hizmet eden uygun iletişim davranışını kullanmayı öğretir (Mancil ve Boman, 2010). 2000 yılından bu yana pek çok çalışma, özellikle otizm spektrum bozukluğu olan çocuk ve ergenlerde kullanılmak üzere en belirgin işlevsel davranış müdahalesi olarak işlevsel iletişim öğretimini göstermiştir (Alpdoğan, 2018; Braithwaite ve Richdale, 2000; Casey ve Merical, 2006; Danov, Hartman, McComas ve Symons, 2010; Erbaş, 2001; Falcomata, 
YYÜ Eğitim Fakültesi Dergisi (YYU Journal of Education Faculty), 2021;18(2)183-212,http://efdergi.yyu.edu.tr,

Roane, Feeney ve Stephenson, 2010; Gibson, Pennington, Stenhoff ve Hopper, 2010; Harding, Wacker, Berg, Lee ve Dolezal, 2009; Mancil, 2006; Mancil ve Boman, 2010; Matson, Turygin, Beighley, Reiske, Tureck ve Matson, 2011). Problem davranışları azaltmada etkili bir müdahale olarak uygulanan işlevsel iletişim öğretiminin uygulanması sürecine ve dikkat edilmesi gereken adımlara izleyen bölümde ayrıntılı yer verilmiştir.
1. Adım: Problem Davranışların İşlevlerinin Belirlenmesi
2. Adım: Problem Davranışın İşlevinin Ortaya Konması
3. Adım: Problem Davranışın Yerine Geçecek İletişim Davranışının Seçilmesi
4. Adım: Veri Toplama Tekniklerine Karar Verme
5. Adım: Çevre Düzenlenmesi
6. Adım: İletişim Davranışını Kullanması İçin Çocuğun Desteklenmesi

7. Adım: Problem Davranışın Pekiştirilmemesi (Sönme)

8. Adım: İletişim Davranışının Pekiştirilmesi (Olumlu Pekiştirme ve Şekil Verme)

9. Adım: İpuçlarının Geri Çekilmesi

10. Adım: Problem Davranış Görüldüğünde Verilecek Tepkiler

Şekil 1. İşlevsel İletişim Öğretiminin Uygulama Adımları

\section{Problem Davranışların İşlevlerinin Belirlenmesi}

Problem davranışların azaltılması ya da tamamen ortadan kaldırılmasında etkili bir müdahale olan işlevsel iletişim öğretiminin ilk adımı, problem davranışın işlevini belirlemektir. Problem davranışın işlevini belirlemede, işlevsel davranışsal değerlendirme ve işlevsel analiz kullanılmaktadır (Alberto ve Troutman, 2013; Cooper vd., 2019).

\section{İşlevsel Davranışsal değerlendirme}

İşlevsel davranışsal değerlendirme, çocuğun öğrenmesini engelleyen problem davranışlarını tetikleyen ya da sürdüren belirli değişkenleri veya durumları tanımlama sürecidir (Johnston ve O'Neill, 2001; Scott, McIntyre, Liaupsin, Nelson, Conroy ve Payne, 2005). İşlevsel davranışsal değerlendirme, hedef davranışın çevre ile olan ilişkisini anlamanın ilk adımıdır (Furniss, 2009). İşlevsel davranışsal değerlendirmede temel amaç, problem davranış ile olası sonuçlar arasındaki neden-sonuç ilişkisini ortaya koymaktır (Iwata ve Dozier, 2008). İyi yürütülmüş bir işlevsel davranışsal değerlendirme bulguları; (a) problem davranışı sürdüren belirli koşullar, (b) problem davranışın yeniden ortaya çıkmasını önlemek için gerekli koşullar ve (c) problem davranışla aynı işleve sahip iletişim davranışı hakkında bilgi sağlar (Iwata ve 
Dozier, 2008). İşlevsel davranışsal değerlendirmede davranışa ilişkin kapsamlı veri toplamak için dolaylı ve doğrudan değerlendirme teknikleri olmak üzere iki farklı veri toplama tekniğinden yararlanılmaktadır (Erbaş, 2001; Erbaş, Kırcaali İftar ve Tekin İftar, 2011).

Dolaylı değerlendirme sürecinde problem davranışı doğrudan gözlemek yerine, problem davranış sergileyen kişiyle veya bu kişiyi en iyi tanıyan kişilerle (anne-baba, öğretmen vb.) görüşmeler yoluyla problem davranışın işlevine ilişkin bilgi toplamak hedeflenmektedir (Paclawskj, Matson, Rush, Smalls ve Vollmer, 2000). Dolaylı değerlendirme teknikleri arasında görüşmeler, kontrol listeleri ve derecelendirme ölçekleri yer almaktadır (Erbaş, 2017; Erbaş, Kırcaali İftar ve Tekin İftar, 2011). Görüşmelerde, çocuğun yaşamındaki önemli kişilere problem davranışın olası işlevleri sorularak problem davranışın kaynağı belirlenmeye çalışılır. Bu veri toplama tekniğinde, problem davranışın olası işlevlerine ilişkin bilgi toplamak amacıyla görüşme formları kullanılmaktadır (O'Neill, Horner, Albin, Sprague ve Newton, 1997). Kontrol listeleri; problem davranışı, davranışa zemin hazırlayan uyaranları, öncülleri ve sonuçları belirlemeye yönelik sorulardan oluşan ölçme araçlarıdır. $\mathrm{Bu}$ değerlendirme araçlarında, davranışın öncülleri ve sonuçlarına yönelik çoğu durumun listelenmesi gereklidir. Derecelendirme ölçekleri ise, problem davranışa ilişkin gözlenen performansı belli bir ölçüte göre derecelemeyi sağlayan araçlardır. Derecelendirme ölçeklerinde öncüllerin ve sonuçların görülme olasılığına ilişkin kestirimler puanlanırken kontrol listelerinde genellikle öncüllere ve sonuçlara ilişkin kestirimler verilen listeden işaretlenir (Erbaş, 2017). Bu teknikler bir işlevsel davranışsal değerlendirme yürütmek için basit ve zaman açısından etkili sayılmaktadır (Iwata ve Dozier, 2008). Dolaylı değerlendirmenin sonuçları, bir problem davranışın işlevini belirlemeye çalışırken yöntem olarak tek başına yeterli değildir fakat bulguları hedef davranışın daha fazla araştırılması için bir ön kılavuz olarak kullanılabilmektedir (Lee, 2014).

Doğrudan değerlendirme teknikleri ise, problem davranışın ortaya çıkma olasılığının en yüksek olduğu doğal ortamlarda problem davranışın doğrudan gözlenmesini içermektedir (Thompson ve Borrero, 2011). Doğrudan değerlendirme tekniklerinde temel amaç, dolaylı değerlendirme teknikleri kullanılarak elde edilen verilerin geçerliğini test etmek ve doğrulamaktır. Doğrudan değerlendirme teknikleri; öncül-davranış-sonuç (ÖDS) kaydı, işlevsel davranışsal değerlendirme gözlemi ve davranış dağılımı çizelgesidir (Erbaş, 2017). Öncül-davranış-sonuç kaydı, çocuğun belli bir ortamda sergilediği davranışlar ve bu davranışların öncesinde ve sonrasında meydana gelen olayların kayıt edilmesinde kullanılmaktadır (Alberto ve Troutman, 2013). ÖDS kaydı ile veri toplama, son derece yararlıdır çünkü bu bulgular araştırmacının doğal ortamda nesnel veri toplamasına izin vererek 
problem davranışı sürdüren doğal durumları ortaya çıkarmaktadır (Neef ve Peterson, 2007). O'Neill vd. (1997) tarafından geliştirilen işlevsel davranışsal değerlendirme gözleminde; işlevsel davranışsal değerlendirme gözlem formu kullanılarak problem davranışları, öncülleri ve sonuçları belirlemek için farklı ortamlar ve farklı zaman dilimlerinde veri toplanmaktadır. Böylece problem davranışın nerede ve ne zaman oluşup veya oluşmadığı belirlenmeye çalışılır (Erbaş, 2017). Davranış dağılım çizelgesi ise, davranış örüntüsünü belirlemek amacıyla kullanılan bir davranış kayıt tekniğidir. Bu veri toplama tekniğiyle, problem davranışın en fazla görüldüğü zaman dilimleri veya etkinlikler gibi davranış öncesi olaylar belirlenmeye çalışılır (Erbaş, Kırcaali İftar ve Tekin İftar, 2011). Dolaylı ve doğrudan değerlendirme teknikleri kullanılarak yapılan işlevsel davranışsal değerlendirme sonucunda problem davranışın işlevine ilişkin hipotez geliştirilir. Problem davranışın işlevine ilişkin geliştirilmiş bu hipotezi doğrulamak amacıyla işlevsel analiz yapılır (Alberto ve Troutman, 2013; Cooper vd., 2019). İzleyen bölümde işlevsel analize ilişkin ayrıntılı bilgi verilmektedir.

\section{İşlevsel analiz}

İşlevsel analiz, işlevsel davranışsal değerlendirme yoluyla elde edilen verilere dayalı olarak geliştirilen ve problem davranışların işlevlerine ilişkin hipotezlerin sınandığg süreçtir (Horner, Albin, Spraque ve Todd, 2000). Iwata, Dorsey, Slifer, Bauman ve Richman (1994) tarafindan oluşturulan işlevsel analizin amacı, en kontrollü ortamlarda problem davranışın doğrudan ve ölçülebilir bir şekilde gözlenmesini sağlayarak problem davranışa yönelik olumlu pekiştirici kaynakları tanımlamaktır (Lee, 2014). Durand'a (1990) göre işlevsel analiz, davranışın işlevini belirlemek için kullanılan en iyi yöntemdir. İşlevsel analizin kullanımına ilişkin öncüllere dayalı analizler ve sonuca dayalı analizler olmak üzere iki farklı yaklaşım benimsenmektedir (Carr ve Durand, 1985; Erbaş, 2017; Iwata vd., 1994).

Öncüllere dayalı analizin amacı, problem davranışın ortaya çıkmasına neden olan öncülleri belirlemektir (Erbaş, Kırcaali İftar ve Tekin İftar, 2011). İşlevsel analiz sürecinde kullanılan öncüllere; yönergenin uzunluğu (Butler ve Luiselli, 2007), yardım düzeyi (Ebanks ve Fisher, 2003), yetişkin ilgisi (Carr ve Durand, 1985) ve etkinliğin zorluk derecesi (Moore ve Edwards, 2003) örnek olarak verilebilir. Bu öncüller, problem davranış ve işlevine ilişkin geliştirilen hipotezleri test etmek için kullanılmaktadırlar. Bu durumlarda problem davranışın sonuçları sabit tutulmakta ve problem davranış olasılığını artıran öncüller sistematik olarak düzenlenmektedir ( Erbaş, 2017).

İşlevsel analiz kullanımına ilişkin benimsenen diğer yaklaşım ise sonuca dayalı analizdir (Erbaş, Kırcaali İftar ve Tekin İftar, 2011). Sonuca dayalı analizde, problem davranış 
sonuçlarını içeren benzetilmiş ortamlar oluşturularak, problem davranışı izleyen belli sonuçların problem davranış üzerindeki etkisi incelenmektedir (Erbaş, 2017). İşlevsel analiz sürecinde kullanılan sonuçlara; ilgi, nesne, etkinlik ve duyusal uyaran elde etme veya kaçma örnek olarak verilebilir. Bu analiz sürecinde davranışı izleyen ve o davranışın ilerde yapılma olasılığını artıran uyaranlar belirlenmektedir (Erbaş, 2001). İşlevsel analiz sürecinde öncüllere dayalı analiz veya sonuca dayalı analiz sonuçlarının güvenilir olması, işlevsel iletişim öğretiminin en üst düzeyde etkili olmasını sağlamaktadır (Lee, 2014).

\section{Problem Davranışın İşlevinin Ortaya Konması}

Problem davranışın işlevini belirlemek için işlevsel davranışsal değerlendirme yapılmasının ardından problem davranışın işlevi belirlenir. Problem davranışın işlevi yüksek ihtimalle sosyal ilgi/dikkat elde etme, nesne elde etme, duyusal uyaran elde etme veya kaçma/kaçınmadır (Alberto ve Troutman, 2013; Cooper vd., 2019; Erbaş, Kırcaali İftar ve Tekin İftar, 2011; Erbaş, 2017). Problem davranışların işlevlerine ilişkin ayrıntılı bilgi yukarıdaki bölümde verilmiştir.

\section{Problem Davranışın Yerine Geçecek İletişim Davranışının Seçilmesi}

Problem davranışın işlevinin belirlenmesinden sonraki adım, problem davranışın yerine geçecek iletişim davranışının belirlenmesidir (Durand, 1990). İşlevsel davranışsal değerlendirme tamamlandığında ve davranışın işlevi belirlendiğinde uygun bir iletişim davranışı geliştirilebilir (Durand, 1990; Mancil, 2006; Mancil ve Boman, 2010). İletişim davranışı; sözel dili kullanma, jest ve mimikleri kullanma, resimlerle iletişim kurma veya yardımcı teknolojik cihazları kullanmayı içerebilir (Durand, 1990; Mancil ve Boman, 2010). $\mathrm{Bu}$ iletişim davranışlarından hangisinin kullanılacağına karar verirken göz önünde bulundurulması gereken dört önemli ölçüt vardır: a) çocuğun davranışı gerçekleştirilebilme becerisi b) davranışı öğretme kolaylığı, c) çocuğun çevresindeki bireylerin iletişim davranışını tanıması ve anlaması ve d) iletişim davranışının genelleme ortamlarında işlevini ne kadar verimli ve etkili bir şekilde yerine getirdiğidir (Mancil ve Boman, 2010). İşlevsel iletişim öğretimi uygularken uygulamacı, problem davranışla aynı işlevi yerine getiren tek bir iletişim davranışı üzerinde odaklanmalıdır (Mancil ve Boman, 2010). Problem davranışın yerine öğretilecek iletişim davranışında bulunması gereken özellikler şöyle sıralanabilir (Erbaş, 2001):

- Öğretilecek iletişim davranışı ile problem davranışın işlevinin aynı olması gereklidir.

- Öğretilecek iletişim davranışına çocuğun çevresindeki kişilerin de tepki vermesi gereklidir. 
- Öğretilecek iletişim davranışı problem davranışla elde edilen pekiştireçlerin elde edilmesini sağlamalıdır.

- Öğretilecek iletişim davranışının toplum tarafından kabul edilebilir olması, bu davranışın sürekliliği ve genellenebilirliği açısından oldukça önemlidir.

- Öğretilecek iletişim davranışının çocuğun çevresindeki önemli kişiler tarafından fark edilebilir olması ve bilinmesi gereklidir.

Problem davranışın yerine geçecek iletişim davranışı belirlendikten sonra müdahale süresince verilerin toplanmasında hangi tekniklerin kullanılacağına karar verilmelidir. İzleyen bölümde buna ilişkin ayrıntılı bilgilere yer verilmektedir.

\section{Veri Toplama Tekniklerine Karar Verme}

Veri toplama; müdahalenin amacına ulaşıp ulaşmadığını, müdahalenin etkililiğini değerlendirme ve müdahalede ne zaman ve nasıl değişiklikler yapmak gerektiğini belirlemek açısından oldukça önemlidir (Özyürek, 2013). Müdahale süresince veri toplama; a) çocuğun performansının doğru tanımlanmasını sağlar, b) müdahaleye zamanından önce son verme veya etkisiz bir müdahaleyi gereksiz yere sürdürme gibi uygun olmayan kararların alınma olasılığını azaltır, c) hedef davranış için belirlenen ölçütün uygunluğuna ilişkin bilgi sağlar ve d) müdahalede herhangi bir uyarlama veya değişiklik yapılması gerektiğinde uygulamacıya bu konuda bilgi sağlar (Alberto ve Troutman, 2013; Collins, 2007; Magg, 1999; Wolery, Bailey ve Sugai, 1988). Veri toplamak için kullanılabilecek birçok farklı veri toplama tekniği mevcuttur. İşlevsel iletişim öğretiminin uygulanması aşamasında davranışın özelliklerine (sürekli bir davranış mı yoksa sayılabilir bir davranış mı) ve koşullara bağlı olarak hangi kayıt tekniğinin kullanılacağına uygulamacı tarafindan karar verilmelidir (Bilmez, 2014).

\section{Çevre Düzenlenmesi}

İşlevsel iletişim öğretiminin uygulanması sürecinde uygulamacılar problem davranışı ortaya çıkarmak ve alternatif iletişim davranışını öğretmek için çevreyi, materyalleri ve etkinlikleri düzenlemelidir. Problem davranışın meydana geldiği çevrede iletişim davranışının öğretilmesi gerekmektedir (Mancil ve Boman, 2010). İşlevsel davranışsal değerlendirme problem davranışın meydana geldiği çevre ve durumlar hakkında ayrıntılı bilgi verir. Örneğin, işlevsel davranışsal değerlendirme sonucunda çocuğun resim etkinliğinde kafasını duvara vurma davranışı sergilediği ortaya çıktığında, iletişim davranışının problem davranışın meydana geldiği resim etkinliğinde öğretilmesi gerekir. Uygulamacılar, iletişim davranışının tekrarlı şekilde uygulanması için firsatlar sağlamak amacıyla materyalleri ve etkinlikleri 
düzenlemelidir. Örneğin, öğretmen çocuğun iletişim davranışını daha sık kullanması için daha çok resim etkinliği planlamalıdır (Franzone, 2009).

\section{İletişim Davranışını Kullanması İçin Çocuğun Desteklenmesi}

İşlevsel iletişim öğretiminin uygulama adımlarından biri de iletişim davranışını kullanması için çocuğun desteklenmesidir. Bu adımda, uygulamacılar çocuğun uygun iletişim davranışını kullanmasına yardımcı olmak için çeşitli ipuçları kullanabilirler. Uygulamacılar çocuğun hata yapmasına izin vermeyen ve öğrenmeyi sağlayan (iletişim davranışını kullanması için yeterli bir müdahale) bir ipucundan başlayarak çocuğun iletişim davranışını kullanmasını sağlamalıdır. İpuçlarının, çocuğun özelliklerine bağlı olarak kullanılması gerekmektedir (Franzone, 2009). Örneğin; dördüncü sınıfa devam eden yüksek işlevli ve sınırlı düzeyde sözel ifade becerisine sahip olan bir çocuk, matematik testinden kaçmak için sürekli arkadaşlarıyla konuşmakta ve gürültü yapmaktadır. Böyle bir durumda öğretmen, çocuğa matematik testi sırasında mola istediğini belirtmek üzere resimli kartlarla iletişim kurmayı öğretebilir. Öğretim sırasında, öğretmen karta çok az dokunarak çocuğun kartı fark etmesi ve kullanması için ipucu verebilir. Böylece, çocuk mola istediğinde kartı öğretmenine verir ve molaya çıkar. Fakat başka bir çocuğa ise, kartı kullanması için fiziksel yardımda bulunabilir. Gerektiğinde çocuğun problem davranışının yerine iletişim davranışının ortaya çıkmasını sağlamak için farklı ipuçları da tercih edilebilir.

\section{Problem Davranışın Pekiştirilmemesi (Sönme)}

İşlevsel iletişim öğretiminin uygulanması sırasında sonraki adım problem davranışların pekiştirilmemesi yani sönmedir. Sönme, problem davranıştan sonra gerçekleşen ve problem davranışın devam etmesini sağlayan pekiştirecin ortadan kaldırılması ve bununla birlikte problem davranışın gittikçe azalıp ortadan kalkmasıdır. Bu, problem davranışları azaltmak veya tamamen ortadan kaldırmak amacıyla kullanılan uygulamalı davranış analizine dayalı müdahalelerdendir (Alberto ve Troutman, 2013; Cooper vd., 2019). İşlevsel iletişim öğretimi, sönme ile birlikte kullanıldığında iletişim davranışı pekiştirilirken problem davranış görmezden gelinir (Kelley, Lerman ve Van Camp, 2002; Shirley, Iwata, Kahng, Mazaleski ve Lerman, 1997; Worsdell, Iwata, Hanley, Thompson ve Kahng, 2000). İşlevsel iletişim öğretiminin uygulanması sırasında, uygulamacı iletişim davranışını öğretirken aynı zamanda sönmeyi uygulayarak problem davranışın hiçbir şeklini pekiştirmez. Örneğin; parka gitmek istediğini belirtmek için sürekli ağlayan bir çocuğa, resimli kartlarla iletişim kurma davranışı öğretilip ağlama davranışı görmezden gelinerek sönme ve işlevsel iletişim öğretimi birlikte kullanılabilir. Böylece çocuğun problem davranışı pekiştirilmezken iletişim davranışı 
pekiştirilmiş olur (Franzone, 2009). Müdahalenin bu aşamasında sönmenin uygulanması, sönme sonucunda azalan davranışın tekrar geri gelmesi ve sönme patlaması gibi olumsuz etkilerle karşılaşılabilir (Sazak Pınar, 2017). Sönme patlaması, sönmenin işlem süreçlerine yer verildiğinde pekiştireci geri çekilen problem davranışın artması ya da çeşitlenmesi durumudur. Uygulamacılar sönme patlamasına karşı hazırlıklı olmalı ve sönmeyi tutarlı bir şekilde uygulamaya devam etmelidir (Özyürek, 2013).

\section{İletişim Davranışının Pekiştirilmesi (Olumlu Pekiştirme ve Şekil Verme)}

Pekiştirme, çocuğun olumlu davranışlarının ardından ona hoşa giden bir uyaran verilmesi ve çocuğun bu olumlu davranışlarının ileride tekrar etme olasılığının artmasıdır (Alberto ve Troutman, 2013; Cooper vd., 2019; Tekin İftar ve Kırcaali İftar, 2012; Yücesoy Özkan, 2013). Pekiştirme; olumlu pekiştirme, olumsuz pekiştirme ve otomatik pekiştirme olmak üzere üçe ayrılmaktadır (Yücesoy Özkan, Kaya ve Gülboy, 2017). Burada işlevsel iletişim öğretiminin uygulama aşaması olan iletişim davranışının pekiştirilmesinde olumlu pekiştirmeye yer verilmektedir.

Olumlu pekiştirme, bir davranışın gerçekleşmesinin hemen ardından ortama hoşa giden bir uyaranın eklenmesi ve bu uyaranla birlikte davranışın ileride tekrarlanma olasılığının artmasıdır (Alberto ve Troutman, 2013; Cooper vd., 2019; Webber ve Scheuermenn, 2008). Müdahalenin bu aşamasında iletişim davranışı için olumlu pekiştirme hızlı ve tutarlı bir şekilde uygulanmalıdır. Olumlu pekiştirmenin iletişim davranışının hemen ardından kullanılması oldukça önemlidir (Besler ve Süzer, 2014). Eğer iletişim davranışına uygun yanıt hemen verilmezse, çocuk iletişim davranışı yerine problem davranışı kullanmaya devam edecektir (Franzone, 2009). Pekiştirmenin geciktirilmesi veya reddedilmesi gibi olası durumlar işlevsel iletişim öğretiminin önemli bir bileşenidir. Çünkü çeşitli nedenlerden dolayı pekiştirme yapılmaması olasıdır: a) Talep edilen pekiştirecin kolayca elde edilememesi (örneğin, yemek hazırlama), b) talep edilen pekiştirecin uygun olmaması (örneğin, sağlık ve hijyenle ilgili olarak kaçma) veya c) çocuğun uygun olan sıklıktan daha fazla pekiştirme talep etmesi. Çocuğun iletişim yoluyla dikkat çekmeye yönelik girişimleri başarısız olduğunda, daha önce pekiştirme aldığı problem davranışı göstermesi muhtemeldir. Pekiştirme reddedildiğinde veya ertelendiğinde iletişim davranışının etkililiği azalır ve problem davranışların ilk haline dönme olasılığı artar (Acotto, 2014). Ayrıca çocuğun iletişim davranışını sergilemesinin ardından çevresindeki tüm bireylerin hızlı ve tutarlı bir şekilde yanıt vermesi ve pekiştirmesi kritik bir öneme sahiptir. Eğer iletişim davranışı öğretilirken çocuğun çevresindeki tüm bireyler aynı ortaklıkta iletişim davranışına yanıt vermezlerse çocuk istenen iletişim davranışını elde 
edemeyecek, problem davranışları azalmayacak ve iletişim davranışını kullanmayacaktır. Böylece çocuk, iletişim davranışı yerine problem davranışı kullanmaya devam edecektir (Franzone, 2009). Bu aşamanın bir başka bileşeni davranış sergilendikten sonra etkili pekiştirme oranını belirlemektir (Richman, Wacker ve Winborn, 2001). İşlevsel iletişim öğretiminin etkili olması için iletişim davranışının problem davranıştan daha yüksek oranda pekiştirilmesi gereklidir (Durand, 1990; Wacker vd., 1990).

$\mathrm{Bu}$ aşamada iletişim davranışının pekiştirilmesini içeren bir başka bileşen de şekil vermedir. Şekil verme; hedef davranışa ulaşmayı sağlayacak başarıyla sergilenen ardışık yaklaşık davranışların ayrımlı pekiştirilmesiyle yeni bir davranışın kazandırılması sürecidir (Scheuermann ve Hall, 2012). Şekil vermede, hedef davranışa benzeyen davranışlar pekiştirilir. Daha sonra pekiştirilen davranışların pekiştirilmesine son verilerek davranış çeşitlendirilir. Çeşitlenmiş davranışlardan hedef davranışa yaklaşan davranışlar, tekrar pekiştirilir. Bu sürece hedef davranış gerçekleşene kadar devam edilir (Özyürek, 2013). İşlevsel iletişim öğretiminin uygulanma aşamasında çocuğa iletişim davranışının öğretilmesinde şekil verme kullanılmaktadır. $\mathrm{Bu}$ aşamada çocuğun iletişim davranışını gerçekleştirmek için gösterdiği iletişim girişimleri pekiştirilir. Örneğin; bir anne problem davranış sergileyen sözel dil becerisi olmayan çocuğuna isteklerini ifade etmesi için problem davranışları yerine sözel becerileri kullanmayı öğretmede şekil vermeyi kullanabilir. Bu aşamada anne ilk olarak çocuğunun isteklerini işaretle ifade etmesini pekiştirir, daha sonra tek sözcüklü iletişim davranışlarını pekiştirir ve son olarak cümle kurarak isteklerini ifade etme davranışını pekiştirir. Çocuk işaret ile isteklerini ifade etme davranışını kazandıktan sonra, tek sözcükle isteklerini ifade etme davranışını pekiştirir ve işaretle isteklerini ifade etme davranışını artık pekiştirmez. Bu sürece çocuk sözel ifade becerilerini kazanana kadar bu şekilde devam edilir (Olçay Gül, 2014). Bu aşamada dikkat edilmesi gereken bir nokta, uygulamacı iletişim davranışını öğretirken şekil vermeyi kullandığında öncelikle iletişim davranışını iyi bir şekilde analiz etmeli ve bu davranışa ilişkin uzun ve kısa dönemli amaçları belirlemelidir. Ayrıca uygulamacı iletişim davranışına ilişkin hangi iletişim girişimlerinin pekiştirileceğini aile ve diğer okul personeli ile paylaşmalı ve tam olarak tutarlılık göstermelidir (Ünlü, 2017). Çocuğa iletişim davranışının öğretilmesi sırasında iletişim davranışı kazandırıldıktan sonra kullanılan ipuçlarının geri çekilmesi de oldukça önemlidir. İzleyen bölümde buna ilişkin ayrıntılı bilgiye yer verilmektedir.

\section{İpuçlarının Geri Çekilmesi}

Özel gereksinimli çocuklarda istendik davranış değişikliğinin sağlanmasında ipuçlarından yararlanmak ve ipucu sürecini etkili bir şekilde kullanmak oldukça önemlidir 
(Fazzio ve Martin, 2010). Bu çocuklara herhangi bir davranış öğretilirken kullanılan ipucu türleri en az 1lımlı olandan (çocuk üzerinde en fazla kontrole sahip) en 1lımlı olana (çocuk üzerinde en az kontrole sahip) doğru şu şekilde sınıflandırılmaktadır: a) Tam fiziksel ipucu, b) kısmi fiziksel ipucu, c) model ipucu, d) görsel ipucu, e) sözel ipucu ve f) jestsel ipucudur (Wolery vd., 1988).

Tam fiziksel ipucu, beceriyi gerçekleştirme süresi boyunca uygulamacının elleriyle çocuğu yönlendirdiği ipucu türüdür. Çoğunlukla uygulamac1, çocuğun elinin üstünden tutar ve beceriyi tamamlamasını sağlar (Genç Tosun, 2014). Çocuk üzerinde en fazla kontrole sahip ipucu türüdür (Ünlü, 2017). Kısmi fiziksel ipucu, beceriyi gerçekleştirme süresi boyunca uygulamacının yardımcı olmak için çocuğa dokunduğu fakat tüm hareketlerini kontrol altına almadığı ipucu türüdür. Bu ipucu türü; dirseğini itme, hafifçe dokunma, hafifçe çekme ya da itme şeklinde çocuğun beceriyi gerçekleştiremediği basamaklarda yardımcı olmak için kullanılır (Genç Tosun, 2014). Örneğin; çocuğun elinin üzerinden tutarak sarı renkli oyuncak arabayı alması sağlandığında tam fiziksel ipucu, sarı renkli oyuncak arabayı alması için koluna hafif temas edildiğinde ise kısmi fiziksel ipucu kullanılmış olur. Model ipucu, çocuktan beklenen tepkinin uygulamacı tarafından gerçekleştirilerek çocuğa yardımda bulunmayı hedefleyen ipucu türüdür (Alberto ve Troutman, 2013). Bu ipucu türünde uygulamac1, öğretilmek istenen becerinin nasıl gerçekleştirildiğini çocuğa model olarak gösterebilir (Tekin İftar ve Kırcaali İftar, 2012). Örneğin; uygulamacı, çocuk ile sınırlı alan boyama çalışırken sınırlı alanı önce kendisi boyayarak sınırlı alanın nasıl boyandığına model olabilir. Görsel ipucu, çocuğun doğru tepkiyi vermesi için uygulamacının onun düzeyine uygun resim, fotoğraf, işaret vb. görselleri kullanmasıdır (Matson, 2009). Örneğin; çocuğa giysi katlama becerisi öğretilirken bu becerinin her bir basamağı resimlerle gösterilerek öğretilebilir. Sözel ipucu, çocuğun doğru tepkiyi vermesi için uygulamacının sözel ifadeler veya kalıplar kullandığı ipucu türüdür. Bu ipucu türü kullanılırken dikkat edilmesi gereken en önemli nokta, hedef uyaran ve sözel ipucunun birbirine karıştırılmamasıdır (Ünlü, 2017). Örneğin; bir çocuğa çorap giyme becerisi öğretilirken "çorabı giy" hedef uyaran, "çorabı yukarı doğru çek" veya "çorabı düzelt" gibi sözel ifadeler ise sözel ipucudur. Son olarak jestsel ipucu ise, çocuğa ne yapacağına ilişkin bilgi verirken el, kol, yüz ve vücut hareketlerinin kullanılarak sunulduğu ipucu türüdür (MacDuff, Krantz ve MacClannahan, 2013). Çocuğa doğru tepkide bulunması öğretilirken parmakla işaret etme, göz oynatma, baş sallama vb. jestsel ipuçlarına örnek olarak verilebilir.

Verilen bu ipuçları, işlevsel iletişim öğretiminin uygulanması sırasında çocuğun özellikleri ve gereksinimlerine bağlı olarak kullanılmaktadır. Müdahalenin bu aşamasında 
iletişim davranışının öğretiminde ilerleme kaydedildikçe veya ölçüt karşılandıktan sonra ipuçları planlı bir şekilde ortadan kaldırılmalıdır. Aksi halde ipuçları geri çekilmediğinde çocukta ipucu bağımlılı̆̆ ortaya çıkabilmektedir. Bu nedenle ipuçlarının geri çekilmesi aşamasında kullanılan ipuçları, aşamalı ve planlı bir şekilde geri çekilmelidir (Genç Tosun, 2014). Bu aşamada dikkat edilmesi gereken birkaç husus bulunmaktadır. Bunlardan birincisi, uygulamacı öğretime başlarken ipuçlarını nasıl geri çekeceğini planlamalıdır. Planlama yapılmazsa, uygulamacı öğretim sırasında gereğinden fazla ipucu kullanabilir ya da etkili ipucunu kullanmayabilir. İkincisi ise ipucunun çok hızlı geri çekilmemesi gereğidir. İpucunun çok hızlı geri çekilmesi, iletişim davranışının öğrenilmemesiyle sonuçlanabilir (Genç Tosun, 2014). Ayrıca ipuçlarının geri çekilmesi aşamasında ipuçlarının aşamalı bir şekilde geri çekilmesine dikkat edilmelidir.

\section{Problem Davranış Görüldüğünde Verilecek Tepkiler}

İşlevsel iletişim öğretiminin son uygulama adımı ise problem davranış görüldüğünde verilecek tepkilerin belirlenmesidir. Burada önemli olan nokta çocuk problem davranış sergilediğinde uygulamacının nasıl tepki vereceğidir. İşlevsel iletişimin öğretimi sırasında çocuk problem davranış sergilediğinde problem davranışları azaltmada kullanılan sonuca dayalı müdalelerden pekiştirme, sönme ve ceza yöntemi kullanılmaktadır (Tiger, Hanley ve Bruzek ve 2008).

İşlevsel iletişim öğretiminin uygulanması sırasında pekiştirme üzerinde çok az kontrol olduğunda (örneğin, akran ilgisi) veya pekiştirmenin ortadan kaldırılmasının çocuk için çok tehlikeli olduğu (örneğin, ciddi düzeyde kendini yaralama davranışı gösteren bir yetişkin) durumlarda problem davranışın pekiştirilmesi gerekebilir. Problem davranış pekiştirilmeye devam edilecek ise iletişim davranışına daha uzun süreli pekiştirme (Peck vd., 1996; Peterson vd., 2005), daha hızlı veya daha yüksek nitelikli bir pekiştirme (Horner ve Day, 1991) ve daha yüksek oranlı bir pekiştirme (Kelley vd., 2002; Worsdell vd., 2000) sağlanmalıdır. Çoğu durumda problem davranış gösteren çocuklara mümkün olduğu kadar pekiştireç sağlanarak, problem davranışın meydana geldiği durumlarda bu davranışların işlevsel olmaması sağlanmaktadır (Erbaş, 2001).

Problem davranışlara verilecek tepkiler arasında diğer bir müdahale olarak sönme yer almaktadır. Sönme ile ilgili ayrıntılı bilgiye yukarıdaki bölümde yer verilmiştir. Sönme olmadan uygulanan işlevsel iletişim öğretimi genellikle problem davranışları azaltmada yeterli düzeyde etkili olmamaktadır (Hagopian, Fisher, Sullivan, Acquisto ve LeBlanc, 1998; Shirley 
vd., 1997; Worsdell vd., 2000). Bu nedenle işlevsel iletişim öğretiminin sönme müdahalesi ile birlikte kullanılması oldukça önemlidir.

Problem davranışlara verilecek diğer bir tepki de cezadır. Ceza, belli bir problem davranışın gelecekte yeniden ortaya çıkma ihtimalini azaltmak için uyaranların uygulanması veya kaldırılmasıdır (Minshawi, Hurwitz, Fodstad, Biebl, Morriss ve McDougle, 2014). Sönme müdahalesi ile birlikte kullanılan işlevsel iletişim öğretiminin çeşitli problem davranışı olan çocuklarda etkili olduğu bilinse de, çoğu araştırmalar bu müdahalenin tüm çocuklar için etkili olmayabileceğini göstermiştir (Hagopian vd., 1998; Hanley vd., 2005). Bu nedenle başarılı bir müdahale olarak cezanın, bazı durumlarda kullanılması önerilmektedir (Tiger vd., 2008). Fakat problem davranışa verilecek tepki olarak cezanın bazı sınırlılıkları bulunmaktadır. Ceza; sözel veya fiziksel saldırganlık davranışlarında artışa neden olabilir, kaçma/kaçınma davranışlarına neden olabilir veya istenmeyen davranışlara model olma ile sonuçlanabilir (Değirmenci, 2014). Ceza içeren uygulamaların bu caydırıcı yönleri; iletişim davranışı pekiştirilmeye devam edilerek, ceza ile sonuçlanan davranışlar açıkça tanımlanarak ve cezayı güvenli bir program eşliğinde sunarak azaltılabilmektedir (Hanley vd., 2005).

Sonuç olarak, işlevsel iletişim öğretiminin uygulanmasında öncelikli olarak problem davranış görüldüğünde verilecek tepki olarak sönmenin kullanılması önerilmektedir. Fakat sönmenin uygulanamadığı veya etkisiz olduğu durumlarda iletişim davranışını destekleyecek şekilde pekiştirme planlanmalı ve problem davranış için ceza uygulanmalıdır (Tiger vd., 2008).

\section{İşlevsel İletişim Öğretiminin Güçlü Yanları ve Sınırlılıkları}

Problem davranışların azaltılmasında kullanılan işlevsel iletişim öğretiminin bir takım güçlü yanları ve sınırlılıkları bulunmaktadır. Bu müdahalenin güçlü yanlarından birincisi, çocukların sosyal olarak kabul edilebilir yollarla iletişim kurmalarına izin vermesidir. Özellikle, çocukları pekiştireç elde etmek için sosyal olarak uygun davranışları kullanarak çevreyi kontrol etmede gerekli olan becerilerle donatmaya teşvik etmekte ve böylece problem davranışları azaltmayı amaçlamaktadır (Halle, Bambara ve Reichle, 2005). İkincisi, problem davranışların zamanla yeniden ortaya çıkmadan hızlı bir azalma göstermesidir. Diğer bir güçlü yanı ise, çocuğun sözel davranış repertuarının zamanla artması sonucunda diğer sosyal kabul edilebilir davranışlarında da artışlar görülebilmesidir (Van Norman, 2005).

İşlevsel iletişim öğretiminin bir müdahale olarak kullanımının en büyük sınırlılığı, doğal ortamlarda iletişim davranışının kullanılması için olumlu pekiştiricilerin her zaman hemen mevcut olmamasıdır (Fisher vd., 2000). Böyle bir durumda çocuk iletişim davranışını sergilediğinde hemen pekiştirilmezse problem davranışta artış görülebilir. Anında pekiştirme 
olmadığından çocuğun iletişim davranışının ortaya çıkmaması muhtemeldir. Bu nedenle sönme patlaması işlevsel iletişim öğretiminin en büyük sınırlılığıdır (Lee, 2014). İşlevsel iletişim öğretiminin diğer bir sınırlılığı ise, pekiştirecin müdahale programını olumsuz etkileyebilecek kadar bireysel isteklere göre yüksek oranda verilmesidir (LeBlanc, Hagopian, Maglieri ve Poling, 2002). Örneğin; çocuk problem davranışı, kaçma amacıyla sergiliyor olabilir. İşlevsel iletişim öğretimi uygulandıktan sonra çocuğun problem davranışı azalıp iletişim davranışının kullanımı artabilir. Fakat çocuk bunu eğitim ortamlarından uzaklaşmak için kullanıp sürekli pekiştireç elde ederse öğrenim yaşantısı, sosyal ve akademik katılımı olumsuz etkilenebilir.

\section{Uygulamacılara ve Ailelere Yönelik Öneriler}

İşlevsel iletişim öğretimini uygularken dikkat etmeniz gereken en önemli nokta, etkili ve planlı bir program geliştirmek ve uygulamaktır. Bu program, müdahale sırasında size açık bir yol haritası çizerek zaman kaybı yaşamanızı önleyecektir. Ayrıca müdahale sırasında yaşadığınız bir takım karışıklıkları gidererek daha verimli bir yol izlemenize yardımcı olacaktır. $\mathrm{Bu}$ süreçte çocuğun yaşamında yer alan herkesle bir iş birliği yapmanız gerektiğini unutmayınız. Bu nedenle müdahale süresince elde ettiğiniz tüm bilgileri, çocuğun yaşamındaki diğer bireylerle paylaşmanız oldukça önemlidir. Çünkü müdahalenin etkililiği ve genellemesi için bu temeldir. Problem davranışın işlevi, ortaya çıktığı ortam ve ortamın özelliklerini dikkatlice gözlemlemelisiniz. Bu; problem davranışı tanıma, çocuk için güvenlik önlemleri alma ve uyaranları kontrol altında tutmanıza yardımcı olacaktır. İletişim davranışını seçerken, problem davranışla aynı amaca ve işleve hizmet ettiğinden emin olmalısınız. Bunun için de ayrıntılı bir değerlendirme size yardımcı olacaktır. Değerlendirme sırasında tüm veri toplama tekniklerini kullanmak sizin için faydalı olacaktır. Tüm değerlendirme tekniklerini kullanmak, problem davranışı ayrıntılı tanımlamanızı sağlayacaktır. Elde ettiğiniz tüm değerlendirme verilerini, diğer bireylerle paylaşmalı ve bununla ilgili bir dosya oluşturmalısınız. Ayrıca hem iletişim davranışı hem de problem davranışa ilişkin sürekli veri toplamanız gerekmektedir. Böylece problem davranışın azalıp azalmadı̆̆ı ve iletişim davranışının artıp artmadığı konusunda bilgi sahibi olabilirsiniz.

Problem davranışla aynı işleve hizmet eden iletişim davranışını seçerken, çocuğun gereksinimlerini karşılayan düzeyine uygun bir iletişim davranışı olmasına dikkat etmelisiniz. Örneğin; sözel ifade becerisi olmayan bir çocuğa iletişim davranışı olarak doğrudan sözel bir beceri öğretmek yerine, resimli kart ya da konuşma cihazı kullanmayı öğretme ile başlayabilirsiniz. İletişim davranışı, çok fazla uğraş gerektirmeyen ve çocuğun kolaylıkla sergileyebileceği bir davranış olmalıdır. Diğer bir önemli nokta da, iletişim davranışının 
pekiştirme yoğunluğu ve sıklığını mutlaka göz önünde bulundurmalısınız. İletişim davranışını pekiştirmekle birlikte problem davranışı pekiştirmeme durumuna da dikkat etmelisiniz. Bazı durumlarda (örn., yüksek düzeyde kendine zarar verme davranışları vb.) problem davranışın pekiştirilmesi gerekebilir. $\mathrm{Bu}$ durumlarda, iletişim davranışını problem davranıştan daha yüksek oran ve sıklıkta pekiştirmelisiniz. İletişim davranışını ilk aşamalarda sürekli olarak pekiştirebilir daha sonra aralıklı pekiştirmelere geçebilirsiniz. İlk olarak çocuğun iletişim davranışını yerine getirmek için gösterdiği girişimleri de pekiştirebilirsiniz.

Çocuğun iletişim davranışını kullanması için çevresel düzenlemeler yapabilir ve çeşitli ipuçları kullanabilirsiniz. Çevresel düzenlemeler ve kullanacağınız ipuçları, çocuğun iletişim davranışını daha kolay ve sık sergilemesine yardımcı olacaktır. Kullanacağınız ipuçlarını çocuğun ve becerinin özelliklerine uygun olarak seçip çocuk iletişim becerisini edindikten sonra planlı bir şekilde geri çekmelisiniz. İletişim davranışının tekrar görülebilme olasılığını artırmak için materyalleri veya etkinlikleri düzenlemelisiniz. Problem davranışın meydana geldiği ortamlarda iletişim davranışını öğretmeye özen göstermelisiniz. Ardından edinilen becerinin farklı ortamlarda sergilenebilmesi için firsatlar oluşturmalısınız. İşlevsel iletişim öğretimini doğal ortamlarda uygulanması, çocuğun iletişim davranışını daha hızlı kazanmasına ve genellemesine yardımcı olacaktır. Bu nedenle öğretim için doğal ortamları tercih etmeniz daha yararlı olacaktır. Son olarak, işlevsel iletişim öğretimini farklı problem davranış azaltma müdahaleleri ile birlikte kullanma, müdahalenin amaca daha hızlı ulaşmasına ve daha etkili olmasına katkı sağlayacaktır. Bu nedenle gerekli durumlarda işlevsel iletişim öğretimi ile birlikte farklı müdahaleleri de (örn., sönmenin işlevsel iletişim öğretimi ile birlikte kullanımı) kullanabilirsiniz.

\section{Sonuç}

Problem davranışlar; çocuğun toplumsal yaşama etkin katılımını engelleyen, hem kendisinin hem de akranlarının güvenliğini tehlikeye düşüren ve sosyal olarak kabul edilmeyen davranışlardır. Özel gereksinimli çocukların, normal gelişim gösteren akranlarına oranla daha yüksek düzeyde ve yoğunlukta davranış problemi sergiledikleri bilinmektedir. Bunun temel nedenlerinden birisi de, çocukların iletişim becerilerindeki yetersizliklerden kaynaklı olarak gereksinimlerini karşılayamaması nedeniyle problem davranış sergileme eğiliminde olmalarıdır. Normal gelişim gösteren çocuklar yaşları ilerledikçe gereksinimlerini karşılamak için iletişim kurarken, özel gereksinimli çocuklar iletişim kurmak için farklı davranış problemleri göstermektedirler. Tüm davranışlar gibi problem davranışlar da belli bir amaca ve 
işleve hizmet etmektedir. Özel gereksinimli çocuklar da problem davranışları genellikle iletişim kurmak amaciyla sergilemektedirler. $\mathrm{Bu}$ nedenle problem davranışlar, özel gereksinimli çocukların yaşamında üzerinde önemle durulması gereken bir konudur.

İşlevsel iletişim öğretimi, özel gereksinimli çocukların problem davranışlarını azaltmada ve iletişim becerilerini arttırmada kullanılan oldukça etkili ve yaygın bir müdahaledir. İşlevsel iletişim öğretimi, problem davranışları etkili ve sosyal iletişim davranışları ile değiştirmenin bir yöntemidir. Sosyal olarak kabul edilebilir iletişim yollarını artıran işlevsel iletişim öğretimi, çocuğa ve çocuğun çevresindeki kişilere daha iyi bir yaşam kalitesi sunarak bağımsızlığa teşvik eden fırsatlar sunmaktadır. $\mathrm{Bu}$ müdahale temelde üç aşamalı bir süreç izlenerek uygulanmaktadır. Birincisi problem davranışın işlevini belirlemek amacıyla işlevsel davranışsal değerlendirme yapma, ikincisi öğretilecek iletişim davranışını belirleme ve üçüncüsü bir müdahale planı geliştirmektir. İşlevsel iletişim öğretiminin uygulama adımları; işlevsel davranışsal değerlendirme yapılması, problem davranışın işlevinin ortaya konması, problem davranışın yerine geçecek iletişim davranışının seçilmesi, veri toplama tekniklerine karar verme, çevre düzenlenmesi, iletişim davranışını kullanması için öğrencinin desteklenmesi, problem davranışın pekiştirilmemesi, iletişim davranışının pekiştirilmesi, ipuçlarının geri çekilmesi ve problem davranış görüldüğünde verilecek tepkiler olarak sıralanmaktadır. Bu adımların her birine dikkat ederek uygulanan müdahale, çocukların problem davranışlarını azaltmakta ve yeni iletişim davranışları kazandırmada oldukça etkili olmaktadir.

\section{Makalenin Bilimdeki Konumu}

\section{Özel Eğitim Bölümü/ Zihin Engellilerin Eğitimi}

\section{Makalenin Bilimdeki Özgünlüğü}

Alanyazında problem davranışların azaltılmasında işlevsel iletişim öğretiminin kullanımına ilişsin araştırmalar yer alsa da ülkemizde buna ilişkin araştırmaların sayıca çok sınırlı olduğu görülmektedir. Ayrıca işlevsel iletişim öğretimi müdahalesinin uygulama sürecini tanıtan ve buna ilişkin kapsamlı bilgiler sunan her hangi bir çalışmaya rastlanmamıştır. $\mathrm{Bu}$ bakımdan, işlevsel iletişim öğretiminin özelliklerini ortaya koyan bu çalışmanın, alanyazına katkı sunması ve uygulamacılara yol göstermesi açısından önemli olduğu düşünülmektedir.

\section{Kaynaklar}


YYÜ Eğitim Fakültesi Dergisi (YYU Journal of Education Faculty), 2021;18(2)183-212,http://efdergi.yyu.edu.tr,

Acotto, C. (2014). The iPad as an alternative reinforcer during functional communication training: Effects on self-injury and aggression. Unpublished doctoral dissertation, Arizona State University.

Alberto, P., \& Troutman, A. C. (2013). Applied behavior analysis for teacher. Upper Saddle River, NJ: Pearson.

Alpdoğan, Y. (2018). Otizm spektrum bozukluğu olan çocuğun problem davranışlarının azaltılmasında ve dersle ilgilenme davranışlarının artırılmasında işlevsel iletişim ögretimin etkililiğinin incelenmesi. Yayımlanmamış yüksek lisans tezi, Abant İzzet Baysal Üniversitesi, Eğitim Bilimleri Enstitüsü, Bolu.

Balc1, A. (2013). Sosyal bilimlerde araştırma: Yöntem, teknik ve ilkeler (10.bask1). Ankara: Pegem Akademi Yayıncılık.

Besler, F. ve Tüzer, T. (2014). Pekiştirme. E. Tekin İftar (Ed.), Uygulamalı Davranış Analizi (214-266). Ankara: Vize Yayıncılık

Bilmez, H. (2014). Veri toplama. E. Tekin İftar (Ed.), Uygulamalı Davranış Analizi (ss. 100143). Ankara: Vize Yayıncilik.

Braithwaite, K. L., \& Richdale, A. M. (2000). Functional communication training to replace challenging behaviors across two behavioral outcomes. Behavioral Interventions, 15, 2136.

Butler, L. R., \& Luiselli, J. K. (2007). Escape-maintained problem behavior in a child with autism: Antecedent functional analysis and intervention evaluation of noncontingent escape and instructional fading. Journal of Positive Behavior Interventions, 9(4), 195202.

Carr, E. G., \& Durand, V. M. (1985). Reducing behavior problems through functional communication training. Journal of Applied Behavior Analysis, 18, 111-126.

Casey, S. D., \& Merical, C. L. (2006). The use of functional communication training without additional treatment procedures in an inclusive school setting. Behavioral Disorders, 32, 46-54.

Collins, B. C. (2007). Moderate and severe disabilities: A foundational approach. Upper Saddle River, NJ: Pearson, Merrill, Prentice-Hall.

Cooper, J.O., Heron, T. E., \& Heward, W. L. (2019). Applied behavior analysis. New Jersey: Person. 
Danov, S. E., Hartman, E., McComas, J. J., \& Symons, F. J. (2010). Evaluation of two communicative response modalities for a child with autism and self-injury. Journal of Speech-Language Pathology and Applied Behavior Analysis, 5(1), 70-79.

Değirmenci, H. D. (2014). Hoşa giden uyaranı çekme. E. Tekin- İftar (Ed.), Uygulamalı Davranış Analizi (ss. 514-563). Ankara: Vize Yayıncılık.

Diken, Ö. (2013). Okul öncesi kaynaştırma ortamlarında dil ve konuşmanın desteklenmesi. B. Sucuoğlu (Ed.), Okul Öncesinde Kaynaştırma (ss.317-354). Ankara: Kök Yayıncılık.

Durand, V. M. (1990). Severe behavior problems: A functional communication training approach. New York: Guilford Press.

Durand, V. M., \& Carr, E. G. (1992). An analysis of maintenance following functional communication training. Journal of Applied Behavior Analysis, 25, 777-794.

Ebanks, M. E., \& Fisher, W. W. (2003). Altering the timing of academic prompts to treat destructive behavior maintained by escape. Journal of Applied Behavior Analysis, 36(3), 355-359.

Erbaş, D. (2001). Gelişimsel geriliği olan çocukların problem davranışlarının azaltılmasında işlevsel iletişim öğretiminin sönmeyle birlikte ve sönme olmaksızın uygulanmasının etkililiklerinin karşılaştırılması. Yayımlanmamış doktora tezi, Anadolu Üniversitesi, Sosyal Bilimleri Enstitüsü, Eskişehir.

Erbaş, D. (2017) Problem davranışların işlevlerini belirleme. D. Erbaş ve Ş. Yücesoy-Özkan (Ed.), Uygulamalı Davranış Analizi (ss. 214-269). Ankara: Pegem Akademi.

Erbaş, D., Kırcaali- İftar, G. ve Tekin-İftar (2011). İşlevsel değerlendirme. Ankara: Kök Yayıclik.

Falcomata, T. S., Roane, H. S., Feeney, B. J., \& Stephenson, K. M. (2010). Assessment and treatment of elopement maintained by access to stereotypy. Journal of Applied Behavior Analysis, 43(3), 513-517.

Fazzio, D., \& Martin, G.L.(2010).Discrete-trials teaching with children with autism: A selfinstructional manual, revised. Unpublished Manuscript, Department of Psychology, University of Manitoba, Winnipeg, Canada.

Fisher, W. W., Thompson, R. H., Hagopian, L. P., Bowman, L. G., \& Krug, A. (2000). Facilitating tolerance of delayed reinforcer during functional communication training. Behavior Modification, 24(1), 3-29. 
Foxx, R. M., \& Meindl, J. (2007). The long-term successful treatment of the aggressive/destructive behaviors of a pre-adolescent with autism. Behavioral Interventions, 22, 83-97.

Franzone, E. (2009). Steps for implementation: Functional communication training. Madison, WI: The National Professional Development Center on Autism Spectrum Disorders, Waisman Center, University of Wisconsin.

Furniss, F. (2009). Assessment method. In J. L. Matson (Eds.), Applied Behavior Analysis for Children with Autism Spectrum Disorders (pp. 33-66). New York, NY: Springer.

Genç Tosun, D. (2014). Davranış öncesi uygulamalar. E. Tekin-İftar (Ed.), Uygulamalı Davranış Analizi (ss. 268-328). Ankara: Vize Yayıncılık.

Gibson, J. L., Pennington, R. C., Stenhoff, D. M., \& Hopper, J. S. (2010). Using desktop videoconferencing to deliver interventions to a preschool student with autism. Topics in Early Childhood Special Education, 29(4), 214-225.

Hagopian, L. P., Fisher, W. W., Sullivan, M. T., Acquisto, J., \& LeBlanc, L. A. (1998). Effectiveness of functional communication training with and without extinction and punishment: A summary of 21 inpatient cases. Journal of Applied Behavior Analysis, 31, 211-235.

Hagopian, L.P., Contrucci Kuhn, S. A., Long, E. S., \& Rush, K. S. (2005). Schedule thinning following communication training: Using competing stimuli to enhance tolerance to decrements in reinforcement density. Journal of Applied Behavior Analysis, 38(2), 177193.

Halle, J.W., Bambara, L.M., \& Reichle, J. (2005). Teaching alternative skills. In S.N. Elliot and J.C. Witt (Eds.), Individualized Supports for Students with Problem Behaviors Designing Positive Behavior Plans (pp.237-274). New York, NY: Guilford Press.

Hanley, G. P., Piazza, C. C., Fisher, W. W., \& Maglieri, K. A. (2005). On the effectiveness of and preference for punishment and extinction components of function-based interventions. Journal of Applied Behavior Analysis, 38, 51-65.

Hanley, G.P., Iwata, B.A., \& Thompson, R.H. (2001). Reinforcement schedule thinning following treatment with functional communication training. Journal of Applied Behavior Analysis, 34(1), 17-31.

Harding, J. W., Wacker, D. P., Berg, W.K., Lee, J. F., \& Dolezal, D. D. (2009). Conducting functional communication training in home settings: A case study and recommendations for practitioners. Behavior Analysis in Practice, 2(1), 21-35. 
Horner, R. H., \& Day, H. M. (1991). The effects of response efficiency on functionally equivalent competing behaviors. Journal of Applied Behavior Analysis, 24, 719-732.

Horner, R.H., Albin, R., Sprague, J., \& Todd, A. (2000). Positive behavior support for students with severe disabilities. In M. E. Snell ve F. Brown (Eds.), Instruction of Student with Severe Disabilities (5th Edition) (pp. 207-243). Upper Saddle River, NJ:Prentice Hall.

Iwata, B. A., Dorsey, M. F., Slifer, K. J., Bauman, K. E., \& Richman, G. S. (1994). Toward a functional analysis of self-injury. Journal of Applied Behavior Analysis, 27, 197-209.

Iwata, B. A., \& Doizer, C. L. (2008). Clinical application of functional analysis methodology. Behavior Analysis in Practice, 1, 3-9.

Johnston, S. S., \& O’Neill, R. E. (2001). Searching for effectiveness and efficiency in conducting functional assessments: A review and proposed process for teachers and other practioners. Focus on Autism and Other Developmental Disabilities, 16(4), 205-214.

Kelley, M. E., Lerman, D. C., \& Van Camp, C. M. (2002). The effects of competing reinforcement schedules on the acquisition of functional communication. Journal of Applied Behavior Analysis, 35, 59-63.

Konrot, A. (2009). İletişim yetersizliği olan çocuklar. A. Ataman (Ed.), Özel Gereksinimli Çocuklar ve Özel Eitime Giriş (ss.196-212). Ankara: Gündüz Eğitim ve Yayıncılık.

Kurtz, P. F., Boelter, E. W., Jarmolowicz, D. P., Chin, M. D., \& Hagopian, L. P. (2011). An analysis of functional communication training as an empirically supported treatment for problem behavior displayed by individuals with intellectual disabilities. Research in Developmental Disabilities, 32, 2935-2942.

LeBlanc, L. A., Hagopian, L. P., Maglieri, K. A., \& Poling, A. (2002). Decreasing the intensity of reinforcement-based interventions for reducing behavior: Conceptual issues and a proposed model for clinical practice. The Behavior Analyst Today, 3, 289-300.

Lee, S. (2014). Teaching delayed gratification: reducing temper tantrums of children with autism spectrum disorders after functional communication training. Unpublished doctoral dissertation, University of Kansas.

MacDuff, G. S., Krantz, P. J., \& MacClannahan, L.E. (2013). Prompts and prompt-fading strategies for people with autism. C. Maurice, G. Green ve R.M. Fox (Eds.), Making A Difference Behavioral Intervention for Autism (pp. 37-50). Texas:Pro-Ed.

Magg, J. W. (1999). Behavior management from theoretical implications to practial applications. London: Singular Publishing Group. 
Mancil, G. R., \& Boman, M. (2010). Functional communication training in the classroom: A guide for success. Preventing School Failure, 54(4), 238-246.

Mancil, R. G. (2006). Functional communication training: A review of the literature related to children with autism. Education and Training in Developmental Disabilities, 41, 213224.

Matson, J. L., Turygin, N. C., Beighley, J., Reiske, R., Tureck, K., \& Matson, M. L. (2011). Applied behavior analysis in autism spectrum disorders: Recent developments, strengths and pitfalls. Research in Autism Spectrum Disorders 6(1), 144-150.

Matson, J. L. (2009). Applied behavior analysis for children with autism spectrum disorders. New York, NY:Springer.

Meyer, L. H., \& Evans, M. (1989). Nonaversive intervention for behavior problems: A manual for home and community. Baltimore: Brookes.

Minshawi, N. F., Hurwitz, S., Fodstad, J. C., Biebl, S., Morriss, D. H., \& McDougle, C. J. (2014). The association between self-injurious behaviors and autism spectrum disorders. Psychology research and behavior management, 7, 125-136.

Moore, J. W., \& Edwards, R. P. (2003). An analysis of aversive stimuli in classroom demand contexts. Journal of Applied Behavior Analysis, 36(3), 339-348.

National Clearinghouse on Autism Evidence and Practice. (2020). Evidence-based practices for children, youth, and young adults with autism. https://ncaep.fpg.unc.edu/ adresinden alındi.

Neef, N. A., \& Peterson, S. M. (2007). Functional behavior assessment. In J. O. Cooper, T. E. Heron ve W. L. Heward (Eds.), Applied Behavior Analysis (2nd ed.) (pp. 500-524). Upper Saddle River, New Jersey: Person Prentice Hall.

O’Neill, R. E., Horner, R. H., Albin, R. W., Sprague, J. R., \& Newtons, J. S. (1997). Functional assessment and program development for problem behavior: A practical handbook. Pacific Grove, CA: Brooks/Cole Publishing.

Olçay Gül, S. (2014). Şekil verme. E. Tekin-İftar (Ed.), Uygulamalı Davranış Analizi (ss. 370388). Ankara: Vize Yayıncilik.

Özyürek, M. (2013). Problem davranışları değiştirme. Ankara: Kök Yayıncılık.

Paclawskj, T. R, Matson, J.L., Rush, K.S., Smalls, Y., \& Vollmer, T.R. (2000). Questions about behavioral function (QABF): A behavioral checklist for functional assessment of aberrant behavior. Research in Developmental Disabilities, 21(3), 223-229. 
Peck, S. M., Wacker, D. P., Berg, W. K., Cooper, L. J., Brown, K. D., Richman, D., \& diğ. (1996). Choice-making treatment of young children's severe behavior problems. Journal of Applied Behavior Analysis, 29, 263-290.

Peterson, S. M., Caniglia, C., Royster, A. J., Macfarlane, E., Plowman, K., Baird, S. J., \& diğ. (2005). Blending functional communication training and choice making to improve task engagement and decrease problem behaviour. Educational Psychology, 25, 257-274.

Richman, D.M., Wacker, D.P., \& Winborn, L. (2001). Response efficiency during functional communication training: Effects of effort on response allocation. Journal of Applied Behavior Analysis, 34, 73-76.

Sazak Pınar, E. (2017). Sonuçlara dayalı teknikler. D. Erbaş ve Ş. Yücesoy-Özkan (Ed.), Uygulamalı Davranış Analizi (ss. 399-439). Ankara: Pegem Akademi.

Scheuermann, B.K., \& Hall, J.A. (2012). Positive behavioral support for the classroom. Upper Saddle River, NJ: Pearson Merrill Prentice Hall.

Scott, T. M., McIntyre, J., Liaupsin, C., Nelson, C. M., Conroy, M., \& Payne, L. D. (2005). An examination of the relation between functioanl behavior assessment and selected intervention strategies with school-based teams. Journal of Postive Behavior Interventions, 7(4), 205-215.

Shirley, M. J., Iwata., B. A., Kahng, S. W., Mazaleski, J. L., \& Lerman, D. S. (1997). Does functional communication training compete with ongoing contingencies of reinforcement? An analysis during response acquisition and maintenance. Journal of Applied Behavior Analysis, 30, 93-104.

Tekin İftar, E. ve Kırcaali İftar, G. (2012). Özel eğitimde yanlışsız öğretim yöntemleri. Ankara: Vize Yayıncilık.

Thompson, R. H., \& Borrero, J. C. (2011). Direct observation. In W. W. Fisher, C.C., Piazza ve H.S. Roane (Eds.). Handbook of applied behavior analysis (pp. 191-205). New York, NY:The Guilford Press.

Tiger, J.H., \& Hanley, G.P. (2004). Developing stimulus specifying stimuli. Journal of Applied Behavior Analysis, 37(4), 517-521

Tiger, J.H., Hanley, G.P., \& Heal, N.A. (2006). The effectiveness of an preschoolers' preferences for variations of multiple-schedule arrangements. Journal of Applied Behavior Analysis, 39(4), 475-48.

Tiger, J. H., Hanley, G. P., \& Bruzek, J. (2008). Functional communication training: A review and practice guide. Behavior Analysis in Practice, 1, 16-23. 
Toğram, B. (2004). Doğal dil öğretim tekniklerinden tepki isteme modelinin öğretilmesinin etkililiği. Yayımlanmamış yüksek lisans tezi, Anadolu Üniversitesi, Sağlık Bilimleri Enstitüsü, Eskişehir.

Topbaş, S. (1999). Dil ve konuşma sorunlu çocukların sesbilgisel çözümleme yöntemi ile değerlendirilmesi ve konuşma dillerindeki sesbilgisel özelliklerin betimlenmesi. Eskişehir: Anadolu Üniversitesi Yayınları.

Ünlü, E. (2017). Yeni davranışları öğretme. D. Erbaş ve Ş. Yücesoy-Özkan (Ed.), Uygulamalı Davranış Analizi (ss. 336-363). Ankara: Pegem Akademi.

Van Norman, R. K. (2005). The effects of functional communication training, choice making, and an adjusting work schedule on problem behavior maintained by negative reinforcement. Unpublished doctoral dissertation, The Ohio State University.

Yücesoy Özkan, Ş. (2013). Okul öncesi sınıflarında sınıf yönetimi ve problem davranışların kontrolu. B. Sucuoğlu ve H. Bakkaloğlu (Ed.), Okul öncesinde kaynaştırma (ss. 191-260). Ankara: Kök Yayıncılık.

Yücesoy Özkan, Ş., Kaya, F. ve Gülboy, E. (2017). Uygun davranışları arttırma. D. Erbaş ve Ş. Yücesoy-Özkan (Ed.), Uygulamalı Davranış Analizi (ss. 271-334). Ankara: Pegem Akademi.

Wacker, D. P., Steege, M. W., Northup, J., Sasso, G., Berg, W., Reimers, T., ... Donn, L. (1990). A component analysis of functional communication training across three topographies of severe behavior problems. Journal of Applied Behavior Analysis, 23, 417-429.

Webber, J., \& Scheuermann, B. (2008). Educating students with Autism: A quick start manual. Austin, Texas: Pro-Ed.

Worsdell, A. S., Iwata, B, A., Hanley, G. P., Thompson, R. H., \& Kahng, S.W. (2000). Effects of continuous and intermittent reinforcement for problem behavior during functional communication training. Journal of Applied Behavior Analysis, 33, 167-179.

Wolery, M., Bailey, D. B., \& Sugai, G. M. (1988). Effective teaching Principles and procedures of applied behavior analysis with exceptional students. Boston:Allyn and Bacon Inc. 


\section{Summary}

\section{Statement of Problem}

Problem behaviours; behaviours that prevents the children themselves and others from learning, prevents effective functioning within society, endangers both their and others security, affects social relations and interactions negatively and at the same time behaviours that does not comply with the children's age and the cultural norms of the society they live in (Carr and Durrand, 1985; Erbaş, 2001). Children may demonstrate various problem behaviours that could cause harm to themselves and others, tantrums, yelling, refusal of participation to activity and not completing a given task. Problem behaviours have a determinate purpose and serves to a certain function (Alberto and Troutman, 2013; Cooper, Heron and Heward, 2019; Erbaş, 2001; Yücesoy Özkan, 2013).

Problem behaviours in children with special needs are a learned behaviour or a behavioural sequence where both of which are a way of communication (Foxx and Meindl, 2007). One of the most researched behavioural intervention in problem behaviour interference is the functional communication teaching (Alpdoğan, 2018; Erbaş, 2001; Hagopian, Contrucci Kuhn, Long ve Rush, 2005; Hanley, Iwata ve Thompson, 2001; Fisher, Thompson, Hagopian, Bowman ve Krug, 2000; Tiger ve Hanley, 2004; Tiger, Hanley ve Heal, 2006).

\section{Purpose of Study}

Purpose of this study is to introduce this intervention to families and educators by presenting comprehensive information on functional communication teaching and its application process.

\section{Method}

With the purpose of contributing to field literature on reducing problem behaviours through functional communication teaching this study; is a descriptive research conducted by literature review. In this research, functional communication teaching used in reducing problem behaviour and application steps of functional communication teaching were introduced within the framework of their general characteristics. To this end, general sources concerning the functional communication teaching discussed here have been acquired and information regarding the intervention has been compiled.

\section{Findings}

\section{Functional Communication Teaching}

Functional communication teaching is a behaviour altering technique based on reinforcement that focuses on defining problem behaviour and teaching a socially appropriate 
communication behaviour carrying the same function as the problem behaviour itself (Carr and Durand, 1985; Durand and Carr, 1992). A three-stage process is followed in the use of functional communication teaching. First step is the completion of the functional behavioural assessment process by the implementer. On the second step, the implementer chooses a communication form that is conceived more suitable and global such as verbal language, sign language, picture communication or another alternative communication device. On the final phase a intervention plan is developed in order to teach the children an acceptable communication behaviour (Macil and Boman, 2010). Steps to be considered in the application process of the functional communication teaching, for reducing problem behaviours, are presented in the following section.

Determining the Functions of Problem Behaviours: The first step in functional communication teaching is to determine the function of the problem behaviour. Functional behavioural assessment and functional analysis are used in determining the function of problem behaviour (Alberto and Troutman, 2013; Cooper et al., 2019).

Presenting the Function of Problem Behaviour: Following the functional behavioural assessment, in order to determine the function of problem behaviour, function of the problem behaviour is presented. The function of the problem behaviour is likely to be gain social interest/attention, gain an object, gain a sensory stimulitions or to escape/escaping (Alberto and Troutman, 2013; Cooper et., 2019; Erbaş, 2017; Erbaş, Kırcaali İftar and Tekin İftar, 2011).

Choosing the Communication Behaviour in Substitution to the Problem Behaviour: A suitable communication behaviour could be developed once the functional behavioural assessment is completed and the function of the behaviour is determined (Durand, 1990; Mancil, 2006; Mancil and Boman, 2010). Communication behaviour may consist using verbal language, using gesture and mimic, communicating via pictures or using assistive technological apparatuses (Durand, 1990; Mancil and Boman, 2010).

Deciding on Data Collection Techniques: Data collection is paramount in determining whether or not the application achieved its ends, assessing the efficiency of the assessment and determining when and how alternations ought to be made in the application (Özyürek, 2013).

Setting the Environment: During the application of the functional communication teaching, implementers should set the environment, materials and activities presenting innumerable opportunities in order to unearth the problem behaviour and to teach alternative communication behaviour (Mancil and Boman, 2010). 
Supporting the Child to use Communication Behaviour: In this step implementers may use variety of prompt in order to aid the child in use proper communication behaviour (Franzone, 2009).

Problem Behaviour not Consolidated (Extinction): The next step during the application of functional communication teaching is the non-reinforcement of the problem behaviour; in other words extinction. Taking place after the problem behaviour, extinction is the withering away of the reinforcer that provides the continuation of the problem behaviour together with the problem behaviour itself (Aberto and Troutman, 2013; Cooper et al., 2019).

\section{Reinforcement of the Communication Behaviour (Positive Reinforcement and} Shaping): On this step, the positive reinforcement for the communication behaviour should be applied in a swift and consistent fashion (Besler and Süzer, 2014). During the application phase of the functional communication teaching, shaping is used in teaching communication behaviour (Olçay Gül, 2014).

Prompt Fading: In this phase, prompt ought to be withdrawn in a gradual and planned fashion (Genç Tosun, 2014).

Reactions when Problem Behaviour Occurs: When the child presents problem behaviour during the functional communication teaching, among result-based applications used in order to reduce problem behaviour, methods of reinforcement, extinction and punishment are used (Tiger and di ̆. ., 2008).

\section{Recommendations for Implementers and Families}

The most important point to be considered while applying functional communication teaching, is to develop and implement a efficient and planned program. When choosing the communication behaviour, you should be sure that the behaviour is serving the same purpose and function as the problem behaviour. While choosing a communication behaviour serving the same function and purpose as the problem behaviour, you should give attention that the communication behaviour meets the needs of the child's requirements. You may use various prompt and also make environmental adjustments for the child to use communication behaviour. You should choose your prompt in accordance with the properties of the children and skill and after the child acquired the communication skill you should withdraw the prompt in a planned fashion. You should organise materials or events to increase the likelihood of the communication behaviour reappearing.

\section{Conclusion}


YYÜ Eğitim Fakültesi Dergisi (YYU Journal of Education Faculty), 2021;18(2)183-212,http://efdergi.yyu.edu.tr,

It is been known that children with special needs presents a higher level and concentration of problem behaviours compared to their counterparts showing normal development. One of the fundamental reasons for this is that children tend to present problem behaviours due to their inadequate communication skills and their inability to meet their needs. While children showing normal development communicate to satisfy their needs as they grow older; children with special needs present different behaviour problems in order to communicate. Also, children with special needs can generally present problem behaviours in order to establish communication. Thus, functional communication teaching is a highly effective and common intervention to reduce problem behaviours of these children and increase their communication skills. 